\title{
Effects of structures of molybdenum catalysts on selectivity in gas-phase propylene oxidation
}

\author{
Martin Šustek a, Blažej Horváth a,*, Ivo Vávra b,c, Miroslav Gál a, Edmund Dobročka b, Milan Hronec a \\ a Faculty of Chemical and Food Technology, Slovak University of Technology, Radlinského 9, 81237 Bratislava, Slovakia \\ b Institute of Electrical Engineering, Slovak Academy of Sciences, Dúbravská cesta 2, 84104 Bratislava, Slovakia \\ c VŠB - Technical University of Ostrava, Nanotechnology Centre, 17.listopadu 15, Ostrava, 70800, Czech Republic
}

\section{A R T I C L E I N F O}

Article history:

Received 10 June 2015

Accepted 25 July 2015

Published 20 November 2015

\section{Keywords:}

Propylene oxide

Epoxidation

Molybdenum oxide

Optical property

Electrochemical property

\begin{abstract}
A B S T R A C T
Molybdenum-based catalysts for the gas-phase oxidation of propylene with air were investigated. Various types of silica-supported molybdenum oxide and molybdenum-bismuth mixed oxide catalysts were prepared from inorganic and organometallic molybdenum precursors using wet impregnation and physical vapor deposition methods. The epoxidation activities of the prepared catalysts showed direct correlations with their nanostructures, which were identified using transmission electron microscopy. The appearance of a partly or fully crystalline molybdenum oxide phase, which interacted poorly with the silica support, decreased the selectivity for propylene oxide formation to below 10\%; non-crystalline octahedrally coordinated molybdenum species anchored on the support gave propylene oxide formations greater than $55 \%$, with $11 \%$ propylene conversion. Electrochemical characterization of molybdenum oxides with various morphologies showed the importance of structural defects. Direct promotion by bismuth of the epoxidation reactivities over molybdenum oxides is disputed.
\end{abstract}

(C) 2015, Dalian Institute of Chemical Physics, Chinese Academy of Sciences. Published by Elsevier B.V. All rights reserved.

\section{Introduction}

The selective oxidation of $\mathrm{C}-\mathrm{H}$ and $\mathrm{C}=\mathrm{C}$ bonds is one of the most widely used processes in the chemical industry for preparing value-added products. Propylene, which contains both $\mathrm{C}-\mathrm{H}$ and $\mathrm{C}=\mathrm{C}$ bonds, is used for the formation of various oxidation products such as acrolein, acrylic acid, and propylene oxide (PO), all of which are industrially important intermediates. However, the allylic hydrogen in the propylene molecule is more prone to attack by nucleophilic oxygen than the $\mathrm{C}=\mathrm{C}$ bond is. Allylic oxidation therefore usually competes strongly with epoxidation [1].

Acrolein is typically manufactured using a bismuth molybdate catalyst and air as the oxidizing agent; $90 \%$ propylene conversion and $85 \%$ selectivity for acrolein are achieved. Bis- muth-molybdenum catalysts for epoxidation reactivities have rarely been reported [2]. PO is usually produced industrially using either the chlorohydrin or Halcon process. These multistep liquid-phase routes involve the formation of stoichiometric amounts of by-products. Novel industrial routes using cumene hydroperoxide or hydrogen peroxide as the oxidant in the liquid phase have been reported [3]. In recent years, several alternative processes for propylene epoxidation have been developed, but the direct gas-phase epoxidation of propylene remains a challenge [4]. Unlike ethylene epoxidation, for which silver-based catalysts have been successfully used commercially for decades, the gas-phase epoxidation of propylene with air is impeded by the presence of a reactive allylic hydrogen atom in the propylene molecule. Propylene therefore tends to give acrolein as the oxidation product instead of PO [5]. Heavily

\footnotetext{
* Corresponding author. Tel: +421-2 59325 655; Fax: +421-2 52495 381; E-mail: blazej.horvath@stuba.sk DOI: 10.1016/S1872-2067(15)60961-5 | http://www.sciencedirect.com/science/journal/18722067 | Chin. J. Catal., Vol. 36, No. 11, November 2015
} 
modified silver-based catalysts give moderate propylene epoxidation, but the PO selectivity barely exceeds $50 \%$ even at low propylene conversions [6]. A continuous supply of chlorinated compounds can increase the selectivity for PO, probably by poisoning non-selective active sites on silver, but the use of chlorinated hydrocarbons causes complications and is not feasible in practical application [5].

A halogen-free, gas-phase reaction system with a copper-doped SBA- 15 catalyst and air as the oxidant was reported to give up to $50 \%$ PO selectivity at propylene conversions below 5\% [7]. Gold was reported to catalyze the epoxidation of propylene by molecular oxygen at atmospheric pressure with selectivity up to $50 \%$ at conversion not exceeding $1 \%$; an increase in conversion, and an increase in the gold particle size, led to a drop in selectivity [8].

Titanosilicates are often used as catalysts for liquid-phase propylene epoxidation by hydrogen peroxide [9]. Other titanosilicate-based catalytic systems use a potentially hazardous mixture of $\mathrm{H}_{2} / \mathrm{O}_{2}$ instead of hydrogen peroxide as the oxidant [10]. Aluminum-containing titanosilicates were reported to catalyze the epoxidation of propylene with molecular oxygen, even without hydrogen as a coreactant, with PO yields up to $11.3 \%$, but with moderate PO selectivity (up to $12.5 \%$ ) [11].

Molybdenum oxides, which have diverse morphologies, depending on the preparation technique, are widely used because of their chemical, electrical, and optical properties [12]. Molybdenum oxides are used industrially as a component of the catalytic system for allylic oxidation of propylene to acrolein, and have also been used for propylene epoxidation. $\mathrm{MoO}_{2}$, which has an unusually high electrical conductivity for a metal oxide, was reported to epoxidize propylene with $42 \%$ PO selectivity, using $\mathrm{N}_{2} \mathrm{O}$ as the oxidizing agent. However, $\mathrm{MoO}_{2}$ is unstable under the reaction conditions used for propylene epoxidation with molecular oxygen. Its oxidation and morphological transformation to $\mathrm{MoO}_{3}$ in the presence of molecular oxygen results in catalyst deactivation [13,14].

Silica-supported molybdenum oxide is the most active among Li, Mg, V, Cr, Mn, Fe, Co, Ni, Cu, Zn, Ga, Zr, Nb, Mo, In, W, $\mathrm{Bi}, \mathrm{Ce}$, and $\mathrm{Sm}$ oxides for gas-phase epoxidation of propylene with molecular oxygen. The most suitable molybdenum precursor is molybdic acid. PO selectivities up to $35 \%$ at propylene conversions up to $15 \%$ at $0.45 \mathrm{MPa}$ have been reported. The conversion was proportional to the oxygen partial pressure. Crystalline $\mathrm{MoO}_{3}$ particles were deemed to be responsible for the epoxidation reactivity [15]. Bismuth molybdate is a wellknown component of catalysts for propylene oxidation to acrolein [16]. However, its presence in crystalline form does not guarantee a good catalytic performance. Electron-donating interactions between the components of the catalyst are considered to be essential in the oxidation of propylene to acrolein. Enhanced activity in acrolein formation is attributed to electronic interactions between the $\left(\begin{array}{lll}0 & 1 & 1\end{array}\right)$ faces of $\alpha-\mathrm{Bi}_{2}\left(\mathrm{MoO}_{4}\right)_{3}$ and the surface of the $\mathrm{MoO}_{3}$ support $[15,17]$. Supported bismuth-molybdenum mixed oxides showed high selectivity in propylene epoxidation, above $50 \%$, using molecular oxygen as the oxidizing agent. The epoxidation reactivity over such catalysts is explained by the promoting effect of bismuth oxides on molybdenum oxide nanoparticles [2].

Various molybdenum precursors such as metallic molybdenum deposited using physical vapor deposition (PVD) [16], ammonium heptamolybdate (AHM) [16], oxoperoxo molybdenum species [18], $\alpha$ - and $\beta$-silicomolybdic acids [19], and organometallic precursors have been used to prepare various types of supported molybdenum oxide species.

Molybdenum uptake by silica from aqueous molybdate or molybdenum polyoxo solutions is generally low, except at low $\mathrm{pH}$, at which silicomolybdates are formed. However, the silicomolybdates are not anchored to the silica surface, but are released into solution [18]. Subsequently, on calcination, the molybdates and silicomolybdates decompose on the catalyst surface, resulting in the formation of different molybdenum oxide agglomerates $[20,21]$. Metastable monoclinic $\beta-\mathrm{MoO}_{3}$ or a more stable orthorhombic $\alpha-\mathrm{MoO}_{3}$ phase is formed, depending on the severity of the calcination conditions [22]. In the oxidation of propylene to acrolein, two partial reactions, i.e., abstraction of the allylic hydrogen and oxygen insertion into the hydrocarbon, occur on different crystal faces of $\alpha-\mathrm{MoO}_{3}$, the former reportedly taking place on the $\left(\begin{array}{lll}0 & 0 & 1\end{array}\right)$ and $\left(\begin{array}{lll}1 & 0 & 0\end{array}\right)$ faces, and the latter on the $\left(\begin{array}{lll}0 & 1 & 0\end{array}\right)$ face [23]. The $\left(\begin{array}{lll}0 & 1 & 0\end{array}\right)$ face was proposed to be the only active one in the formation of $\mathrm{CO}_{2}$ [24]. In addition, the crystal structure of $\alpha-\mathrm{MoO}_{3}$ comprises distinct forms of oxygen in terms of formal negative charges (influencing the nucleophilicity) and vacancy formation energy, the symmetric bridging oxygen atom being the most nucleophilic and most prone to vacancy formation [23]. These parameters, combined with the effects of crystallinity, and potentially of other doping metals, result in the presence of a large number of different active species on $\mathrm{MoO}_{x} / \mathrm{SiO}_{2}$ catalysts prepared from $\mathrm{AHM}$, leading to different catalytic activity in propylene oxidation.

It has been suggested that to achieve higher dispersion of molybdenum oxide species on the silica surface, a molybdenyl acetylacetonate precursor is more suitable than AHM, because it gives better grafting of molybdenum via $\mathrm{Si}-\mathrm{O}-\mathrm{Mo}$ linkages [25]. Use of an SBA-15 support and $\mathrm{MoO}_{2}$ (acac) $)_{2}$ leads to the formation of oligomolybdate and/or polymolybdate species at molybdenum contents $<12 \mathrm{wt} \%$; above this value, segregated polycrystalline $\mathrm{MoO}_{3}$ is formed [26].

Molybdyl chloride can serve as a catalyst for various Lewis-acid-catalyzed reactions, e.g., acylations or redox processes (such as oxidation of alcohols), in the liquid phase or as a heterogenized homogeneous complex. In these liquid-phase application, molybdenyl chloride tends to form octahedral complexes $\mathrm{MoO}_{2} \mathrm{Cl}_{2} \mathrm{~L}_{2}$ ( $\mathrm{L}$ is a solvent molecule or ligand) almost exclusively [18]. Along with its Lewis acidity, $\mathrm{MoO}_{2} \mathrm{Cl}_{2}$ exhibits another promising property, which helps to anchor it on the support: in the solid state, its structure consists of a two-dimensional network of -0-Mo-O- chains, with hexacoordinated molybdenum atoms [27]. In comparison with the traditional AHM precursor, $\mathrm{MoO}_{2} \mathrm{Cl}_{2}$ is therefore a promising molybdenum source for depositing less-aggregated, better-anchored molybdenum species.

Molybdyl chloride is typically prepared with difficulty by the reaction of molybdenum oxide or sulfide using a dry oxygen-chlorine mixture at elevated temperatures, because 
$\mathrm{MoO}_{2} \mathrm{Cl}_{2}$ readily hydrolyzes to give $\mathrm{MoO}_{3}$ :

$$
\mathrm{MoO}_{2} \mathrm{Cl}_{2}+\mathrm{H}_{2} \mathrm{O} \rightarrow \mathrm{MoO}_{3}+2 \mathrm{HCl}
$$

However, under hydrothermal conditions, the equilibrium of reaction (1) can be shifted toward $\mathrm{MoO}_{2} \mathrm{Cl}_{2}$ [28]. Under ambient conditions, excess $\mathrm{HCl}$ in the solution can shift the equilibrium toward the oxychloride. The molybdenum in solid $\mathrm{MoO}_{3}$ forms polymeric [ $\mathrm{MoO}_{6}$ ] octahedra, and upon depolymerization and hydration in $\mathrm{HCl}(6 \mathrm{~mol} / \mathrm{L})$, monomeric $\left[\mathrm{MoO}_{2} \mathrm{Cl}_{2}\left(\mathrm{H}_{2} \mathrm{O}\right)_{2}\right]$ species are released into solution $[29,30]$.

Although molybdenum oxides have some epoxidation activity, the attribution of different forms of molybdenum oxide to preferred reaction routes in propylene oxidation needs further clarification. Some issues are addressed in the present paper: (i) the effect of the molybdenum precursor on the morphology of the resulting catalyst, (ii) the effect of the morphology of the supported molybdenum oxide phase on the catalytic activity, and (iii) the function of bismuth, i.e., whether or not bismuth and molybdenum have a synergistic effect on epoxidation.

In the present work, we focused on supported molybdenum oxides as catalysts for the gas-phase oxidation of propylene with molecular oxygen. PVD and wet impregnation methods were used for the preparation of molybdenum catalysts deposited on fumed silica (Aerosil 200 ${ }^{\circledR}$ ), using different types of inorganic and organometallic molybdenum and bismuth precursors. The influence of the molybdenum precursor and preparation method on the formation of molybdenum oxides with different structure and catalytic properties was investigated.

\section{Experimental}

For the catalysts prepared using PVD, a molybdenum layer was deposited by magnetron sputtering on oxidized silicon wafers of thickness $0.6 \mathrm{~mm}$ with a surface roughness of $0.6 \mathrm{~nm}$, at a substrate temperature of $-50{ }^{\circ} \mathrm{C}$. Molybdenum deposition was performed in an argon atmosphere at $5 \mathrm{~Pa}$. In the case of PVD-prepared bismuth-molybdenum samples, a bismuth layer was formed using the same procedure.

For the other catalysts, a fumed silica, i.e., Aerosil 200, support was used. The support was dried overnight at $200{ }^{\circ} \mathrm{C}$ prior to deposition of molybdenum or bismuth precursors. The amount of deposited molybdenum precursor was calculated to correspond to $10 \%$ of $\mathrm{MoO}_{3}$ in the calcined samples.

AHM was deposited from aqueous solution (0.5\%). A suspension of silica in the aqueous solution was stirred overnight, the solvent was evaporated under vacuum, and the residue was dried at $200{ }^{\circ} \mathrm{C}$, milled, and calcined in static air at $600{ }^{\circ} \mathrm{C}$ for $5 \mathrm{~h}$. $\mathrm{MoO}_{2} \mathrm{Cl}_{2}\left(\mathrm{H}_{2} \mathrm{O}\right)_{2}$ and $\mathrm{MoO}_{2} \mathrm{Cl}_{2}$ precursors were introduced similarly, using $\mathrm{HCl}$ solution $(6 \mathrm{~mol} / \mathrm{L})$ as the solvent for the former and anhydrous toluene for the latter. $\mathrm{MoO}_{2}$ (acac) 2 was introduced using the same procedure as for the $\mathrm{MoO}_{2} \mathrm{Cl}_{2}$ precursor.

In the impregnated catalysts, bismuth was introduced from aqueous glycerol solution (0.5\%) of bismuth nitrate, typically in an amount corresponding to a $1 \%-10 \% \mathrm{Bi}_{2} \mathrm{O}_{3}$ loading in the final catalyst. In some cases, tetraethyl orthosilicate (TEOS) was added to the suspension, in a TEOS: $\mathrm{SiO}_{2}$ ratio of $1: 10$; the suspension was autoclaved at $150{ }^{\circ} \mathrm{C}$ for $24 \mathrm{~h}$, the solvent was evaporated, and the residue was dried, milled, and calcined as described above.

The Aerosil 200-supported catalysts were pressed at 20 $\mathrm{MPa}$ and then crushed and sieved to a grain size of $0.3-0.6 \mathrm{~mm}$.

The catalytic reactions were performed at $400{ }^{\circ} \mathrm{C}$ in a fixed-bed glass reactor loaded with $2 \mathrm{~g}$ of catalyst. The flow rates of air and propylene were $70 \mathrm{~mL} / \mathrm{min}$ and $4 \mathrm{~mL} / \mathrm{min}$, respectively. The reaction products were identified using a Shimadzu Pyr-GCMS-QP 2010 Ultra system with a $50 \mathrm{~m}$ Crossbond capillary column, and analyzed on-line using a Chrompack gas chromatography system with Porapak and Carbosieve columns.

X-ray diffraction (XRD) patterns were obtained using a Bruker D8 Discover diffractometer in a parallel beam geometry with a parabolic Goebel mirror in the primary beam, in grazing incidence mode with an angle of incidence of $1.5^{\circ}$. Transmission electron microscopy (TEM) was performed using a JEOL $1200 \mathrm{EX}$ microscope operated at an accelerating voltage of 120 $\mathrm{kV}$. Ultraviolet/visible (UV/Vis) spectra were obtained using a Shimadzu UV-2450 spectrometer. Voltammetric patterns were recorded using an Autolab PGSTAT-20 apparatus with a carbon paste working electrode, $\mathrm{Ag} / \mathrm{AgCl}$ reference electrode, and platinum grid counter electrode, in acetate buffer $(0.2 \mathrm{~mol} / \mathrm{L})$.

\section{Results and discussion}

\subsection{Catalyst characterization}

Silica-supported catalysts with molybdenum and bismuth oxides in close vicinity were prepared by depositing metallic molybdenum and bismuth on $\mathrm{SiO}_{2}$-coated silicon wafers by magnetron sputtering, followed by oxidation in air. In the first step, nanorods of metallic molybdenum were deposited using a previously reported procedure [14]. The use of a high pressure of argon, i.e., $5 \mathrm{~Pa}$, during molybdenum deposition resulted in a discontinuous molybdenum film. Voids between molybdenum nanorods are thought to prevent the formation of large molybdenum oxide particles during subsequent oxidation of the nanorods. In the second step, a layer of bismuth was deposited on top of the discontinuous molybdenum film (Fig. 1(a)), and the sample was annealed in argon at $280{ }^{\circ} \mathrm{C}$. Because of its low melting point, bismuth tends to migrate on the molybdenum film, forming islands of diameter 50-200 nm (Fig. 1(b)). To decrease the aggregation of metallic bismuth, a sandwichstructured sample was prepared with alternating molybdenum and bismuth layers, each of thickness $15-30 \mathrm{~nm}$. This method limits the size of the bismuth islands to $>25 \mathrm{~nm}$ (Fig. 1(c) and (d)). Oxidation of the resulting wafers led to crystallization of $\mathrm{MoO}_{3}, \mathrm{Bi}_{2} \mathrm{O}_{3}$, and $\mathrm{Bi}_{2}\left(\mathrm{MoO}_{4}\right)_{3}$ phases (Fig. 5(4)).

In the case of Aerosil 200-supported catalysts, the use of AHM led to collapse of the silica nanoparticle structure (Fig. 2). The silica nanospheres of the parent Aerosil 200 support, of diameter $12 \mathrm{~nm}$, aggregated in aqueous AHM solution, giving agglomerates of sizes $>500 \mathrm{~nm}$. The dissolution of small silica particles via reaction (2) prevents the deposition of molybdenum oxides on nanosilica starting from the AHM precursor. 


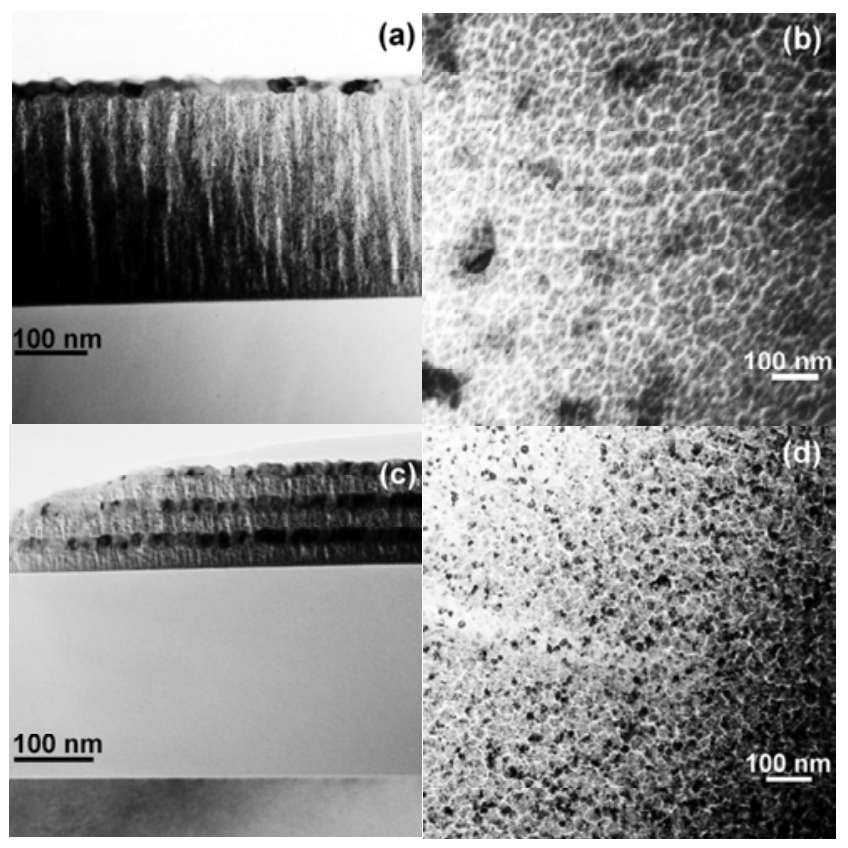

Fig. 1. TEM images of bismuth-doped molybdenum catalyst prepared using PVD. Side view (a) and top view (b) of a $10 \mathrm{~nm}$ bismuth layer deposited on a $200 \mathrm{~nm}$ molybdenum layer; Side view (c) and top view (d) of 3-3 layers of bismuth and molybdenum.

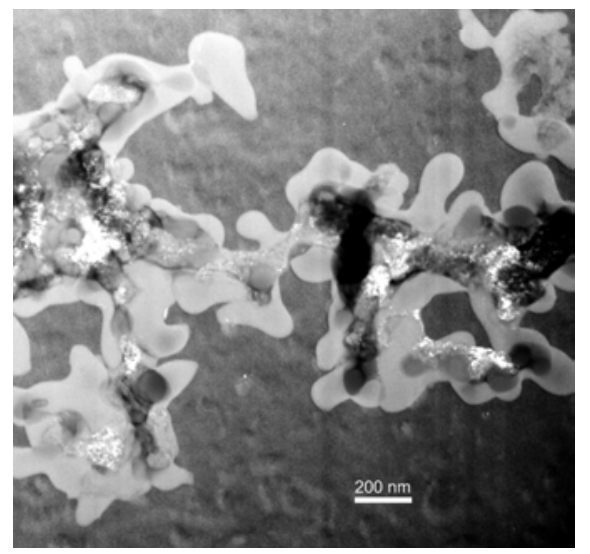

Fig. 2. TEM image of $10 \% \mathrm{AHM} / \mathrm{SiO}_{2}$-Aerosil 200 sample calcined at $600{ }^{\circ} \mathrm{C}$. Deliquescent, lighter substructure is $\mathrm{SiO}_{2}$, darker deposit is amorphous $\mathrm{MoO}_{x}$, and white areas in $\mathrm{MoO}_{x}$ deposit are crystalline $\mathrm{MoO}_{3}$.

$12 \mathrm{Mo}_{7} \mathrm{O}_{24}{ }^{6-}+7 \mathrm{SiO}_{2}+22 \mathrm{H}_{2} \mathrm{O} \rightarrow 7 \mathrm{SiMo}_{12} \mathrm{O}_{40} 0^{4-}+44 \mathrm{OH}^{-}$

The uncontrolled dissolution of silica in the AHM solution and the uncontrolled thermal decomposition of silicomolybdates during calcination led to the formation of polycrystalline $\mathrm{MoO}_{3}$ particles, at least some of which were shown by XRD to have a well-defined $\alpha-\mathrm{MoO}_{3}$ structure (Fig. 5(2)).

However, unlike SBA-15 (reported in [25]), the Aerosil 200 support failed to prevent $\mathrm{MoO}_{3}$ crystallization and resulted in a more pronounced crystallinity in the case of the AHM precursor (Fig. 5(3)). The deposition of molybdenyl acetylacetonate does not cause disintegration of the silica nanospheres and leads to the formation of large $\mathrm{MoO}_{3}$ particles, mostly separated from the silica particles (Fig. 3). It is worth noting that in the case of the AHM precursor, the $\mathrm{MoO}_{3}$ phase crystallizes adjacent to the deliquescent $\mathrm{SiO}_{2}$ support, as seen in Fig. 2 .

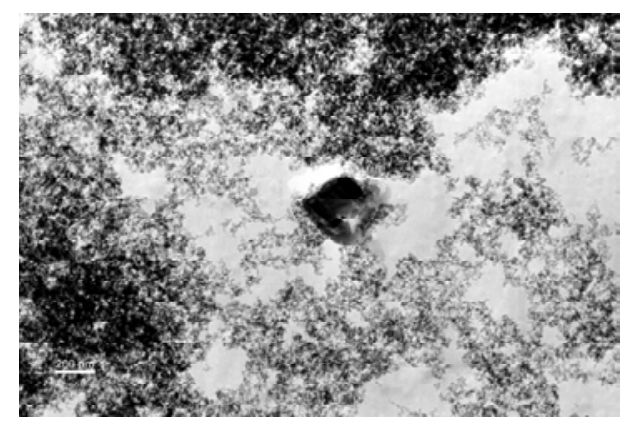

Fig. 3. TEM image of $10 \% \mathrm{MoO}_{2}(\mathrm{acac})_{2} / \mathrm{SiO}_{2}$-Aerosil 200 sample calcined at $600{ }^{\circ} \mathrm{C}$. Large particle in the center is crystalline $\mathrm{MoO}_{3}$, and smaller spheres are $\mathrm{SiO}_{2}$ particles of size practically identical to those in parent Aerosil 200.

The deposition of $\mathrm{MoO}_{2} \mathrm{Cl}_{2}$ from anhydrous toluene solution does not affect the morphology of the support; the size and shape of the silica nanoparticles remain unchanged in the final catalyst. No particles other than those of the support are visible using TEM. The XRD patterns show only the background of amorphous silica, indicating the absence of any significant amounts of crystalline phases. In contrast, the $\mathrm{MoO}_{2} \mathrm{Cl}_{2}\left(\mathrm{H}_{2} \mathrm{O}\right)_{2}$ precursor, deposited from an aqueous solution of $\mathrm{HCl}$, led to agglomeration of the silica support, as can be clearly seen in the TEM images (Fig. 4).

This agglomeration is attributed not to the molybdenum precursor itself, but to a dissolution-precipitation process, because the silica nanopowders themselves are partly soluble under strongly acidic conditions. Unlike AHM and molybdyl acetylacetonate, $\mathrm{MoO}_{2} \mathrm{Cl}_{2}\left(\mathrm{H}_{2} \mathrm{O}\right)_{2}$ led to formation of XRD-amorphous molybdenum species (Fig. 5(1)). For the $\mathrm{MoO}_{2}$ (acac) 2 and AHM precursors, a calcination temperature of $600{ }^{\circ} \mathrm{C}$ was high enough for the formation of crystalline $\mathrm{MoO}_{3}$, therefore crystallization of $\mathrm{MoO}_{3}$ in the case of the $\mathrm{MoO}_{2} \mathrm{Cl}_{2}\left(\mathrm{H}_{2} \mathrm{O}\right)_{2}$ precursor was hindered not because it was thermodynamically impossible, but because of the nature of the precursor.

The UV-Vis spectra indicate that in the case of anhydrous $\mathrm{MoO}_{2} \mathrm{Cl}_{2}$ as the molybdenum source, molybdenum oxide is practically absent from the catalyst, indicating sublimation of volatile anhydrous $\mathrm{MoO}_{2} \mathrm{Cl}_{2}$ instead of grafting on the silica surface.

When $\mathrm{MoO}_{2} \mathrm{Cl}_{2}\left(\mathrm{H}_{2} \mathrm{O}\right)_{2}$ was used as the molybdenum source, the amount of deposited molybdenum (which was proportional to the absorbance in the region 200-400 nm) did not differ from the amounts of molybdenum deposited using AHM or

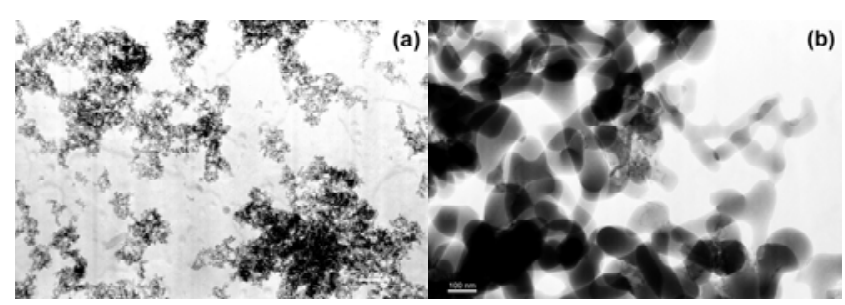

Fig. 4. TEM images of $10 \% \mathrm{MoO}_{2} \mathrm{Cl}_{2} / \mathrm{SiO}_{2}$-Aerosil 200 samples calcined at $600{ }^{\circ} \mathrm{C}$, produced using anhydrous $\mathrm{MoO}_{2} \mathrm{Cl}_{2}$ precursor (a) and acidified aqueous precursor, $\mathrm{MoO}_{2} \mathrm{Cl}_{2}\left(\mathrm{H}_{2} \mathrm{O}\right)_{2}$ (b). 


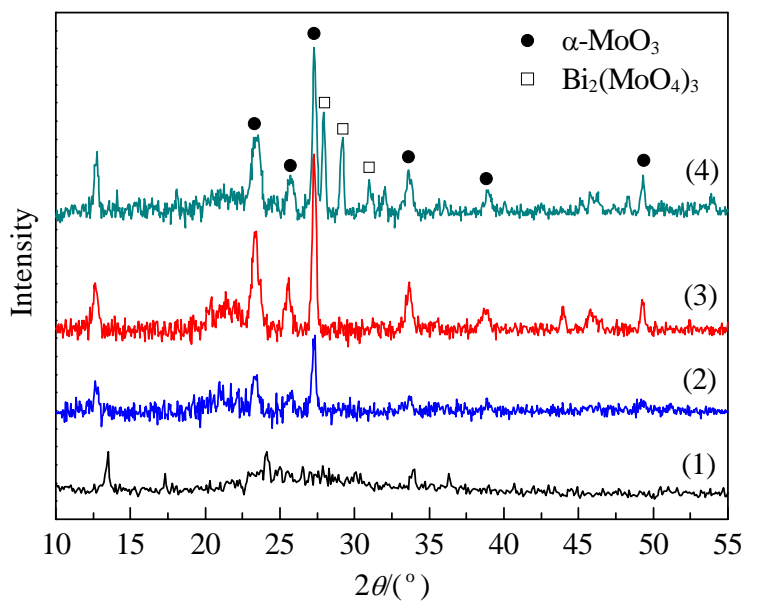

Fig. 5. XRD patterns of $\mathrm{MoO}_{x} / \mathrm{SiO}_{2}$ catalysts prepared from various molybdenum precursors. (1) $\mathrm{MoO}_{2} \mathrm{Cl}_{2}\left(\mathrm{H}_{2} \mathrm{O}\right)_{2}$; (2) AHM; (3) $\mathrm{MoO}_{2}$ (acac) ; (4) Bimetallic bismuth-molybdenum catalyst prepared using PVD. Samples were calcined in static air at $600^{\circ} \mathrm{C}$.

molybdyl acetylacetonate precursors, therefore an aqueous precursor prevents molybdenum loss caused by sublimation of the precursor.

Despite the apparently complete separation of the $\mathrm{MoO}_{3}$ and $\mathrm{SiO}_{2}$ phases, as seen in Fig. 3, some electronic interactions between these components should be observed for the acetylacetonate precursor. The absorption edge energy of the $\mathrm{MoO}_{2}$ (acac) 2 -based sample resembles those of the AHM- and $\mathrm{MoO}_{2} \mathrm{Cl}_{2}\left(\mathrm{H}_{2} \mathrm{O}\right)_{2}$-based ones rather than that of a mechanical mixture of $\mathrm{MoO}_{3}$ and $\mathrm{SiO}_{2}$ (Fig. 6(d)).

The UV-Vis spectra of the samples prepared from all three precursors show three overlapping absorption bands, at 220, 250, and $320 \mathrm{~nm}$, respectively (Fig. 6(a), (b), and (c)). Absorption bands below $300 \mathrm{~nm}$ are generally ascribed to tetrahedrally coordinated molybdenum species, and those at higher wavelengths are attributed to distorted octahedral coordination [15]. AHM concentrations in the range $1 \%-10 \%$ gave practically the same UV-Vis patterns, indicating the same molybdenum-support interactions in the concentration range tested
(Fig. 6(a)). The distribution of particular forms of molybdenum was most concentration sensitive for the $\mathrm{MoO}_{2} \mathrm{Cl}_{2}\left(\mathrm{H}_{2} \mathrm{O}\right)_{2}$ precursor; at low $\mathrm{MoO}_{3}$ contents, the tetrahedral form dominated, with a shift toward the formation of octahedral species with increasing $\mathrm{MoO}_{3}$ concentration (Fig. 6(c)).

The absorption edge energy, determined from Tauc's plots, for all the precursors at $10 \% \mathrm{MoO}_{3}$ loadings, were in the narrow interval 3.6-3.7 eV. The edge energy for molybdenum oxides on silica supports usually range from 3.3 to $3.8 \mathrm{eV}$, approaching the value of $3.0 \mathrm{eV}$ typical of bulk crystalline $\mathrm{MoO}_{3}$, showing the presence of more aggregated polyoxo species; a decrease in aggregation increases the edge energy [15]. However, the edge energy determined from the plots in Fig. 6(d) only reflects the nature of the absorption bands with the lowest edge energy, i.e., the highest wavelengths. They therefore only represent octahedrally coordinated molybdenum. At $\mathrm{MoO}_{3}$ content of $10 \%$, the amount of octahedral species does not greatly depend on the nature of the molybdenum precursor. In contrast, at higher molybdenum loadings, all the molybdenum precursors gave similar amounts of octahedral species, with similar absorption edge energy.

Supported and unsupported molybdenum oxides generally consist of mixtures of isolated tetrahedral and distorted octahedral sites. In the case of an $\mathrm{SiO}_{2}$ support, the isolated tetrahedral sites absorb in the region $<300 \mathrm{~nm}$, indicating stronger electronic interactions between molybdenum and silica and/or better distribution of the supported molybdenum species. However, it should be mentioned that octahedral molybdenum species lead to more moderate weakening of the C-C bonds in the adsorbed propylene molecules, and are therefore expected to perform better in propylene epoxidation [15,31].

Tetrahedrally coordinated molybdenum species are stronger electron acceptors than octahedrally coordinated ones, therefore in the case of the $\mathrm{MoO}_{2} \mathrm{Cl}_{2}\left(\mathrm{H}_{2} \mathrm{O}\right)_{2}$ precursor at $1 \%$ $\mathrm{MoO}_{3}$ loading, a stronger electronic interaction between molybdenum and the support in the calcined sample is evident from the UV-Vis spectrum. In the cases of the AHM and $\mathrm{MoO}_{2}$ (acac) 2 precursors, which show some degree of crystallinity, as shown by TEM and XRD, the value of the bandgap edge
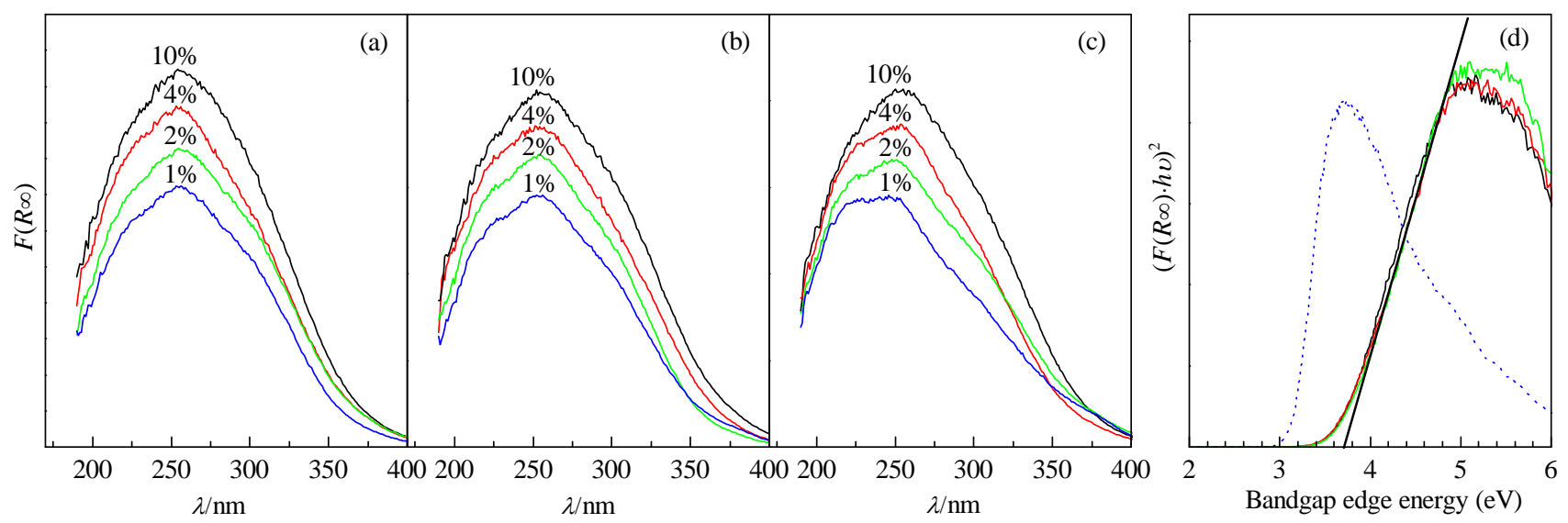

Fig. 6. UV-Vis spectra of $\mathrm{MoO}_{x} / \mathrm{SiO}_{2}$-supported samples, which depend on the nature of the molybdenum precursor, for $\mathrm{MoO}_{3}$ loadings of $10 \%$, $4 \%$, $2 \%$, and 1\%. (a) AHM precursor; (b) $\mathrm{MoO}_{2}$ (acac) 2 precursor; (c) $\mathrm{MoO}_{2} \mathrm{Cl}_{2}\left(\mathrm{H}_{2} \mathrm{O}\right)_{2}$ precursor; (d) Tauc's plots of $10 \% \mathrm{MoO}_{3} / \mathrm{SiO}_{2}$ catalysts prepared from the three precursors (overlapping full lines) and for mechanical mixture of $10 \% \mathrm{MoO}_{3}$ and $\mathrm{SiO}_{2}$ (dotted line). 
energy, 3.6-3.7 eV, is not surprising, and indicates the presence of octahedral polyoxo molybdenum species, which are, however, different from those found in a mechanical mixture of $\mathrm{MoO}_{3}$ and $\mathrm{SiO}_{2}$. However, as the $\mathrm{MoO}_{2} \mathrm{Cl}_{2}\left(\mathrm{H}_{2} \mathrm{O}\right)_{2}$ precursor did not result in any observable crystallinity, less aggregation of molybdenum species is expected for this precursor (catalyst samples using the $\mathrm{MoO}_{2} \mathrm{Cl}_{2}\left(\mathrm{H}_{2} \mathrm{O}\right)_{2}$ precursor were prepared and analyzed repeatedly, without observing the formation of a crystalline phase). The absence of crystallinity in this case, and the bandgap edge energy identical to those of catalysts showing crystallinity, necessitates the presence of similar molybdenum polyoxo domains in all cases; however, in the case of the $\mathrm{MoO}_{2} \mathrm{Cl}_{2}\left(\mathrm{H}_{2} \mathrm{O}\right)_{2}$ precursor, these domains lack long-range geometric order.

Voltammetric measurements were performed to qualitatively investigate the effect of a specific precursor on the nature of the resulting molybdenum oxides. The voltammetric responses of all three samples, at the same sweep rate $(20 \mathrm{mV} / \mathrm{s})$, show reduction peaks $A, B$, and $C$ during the first voltammetric cycle (Fig. 7(a)). The first two peaks, A and B, are suggested to arise from intercalation of sodium cations from the electrolyte into polyoxo molybdenum structure [32-34]. The presence of several intercalation peaks suggests that $\mathrm{Na}^{+}$insertion occurs at energetically distinct reaction sites within molybdenum oxide structure [33].
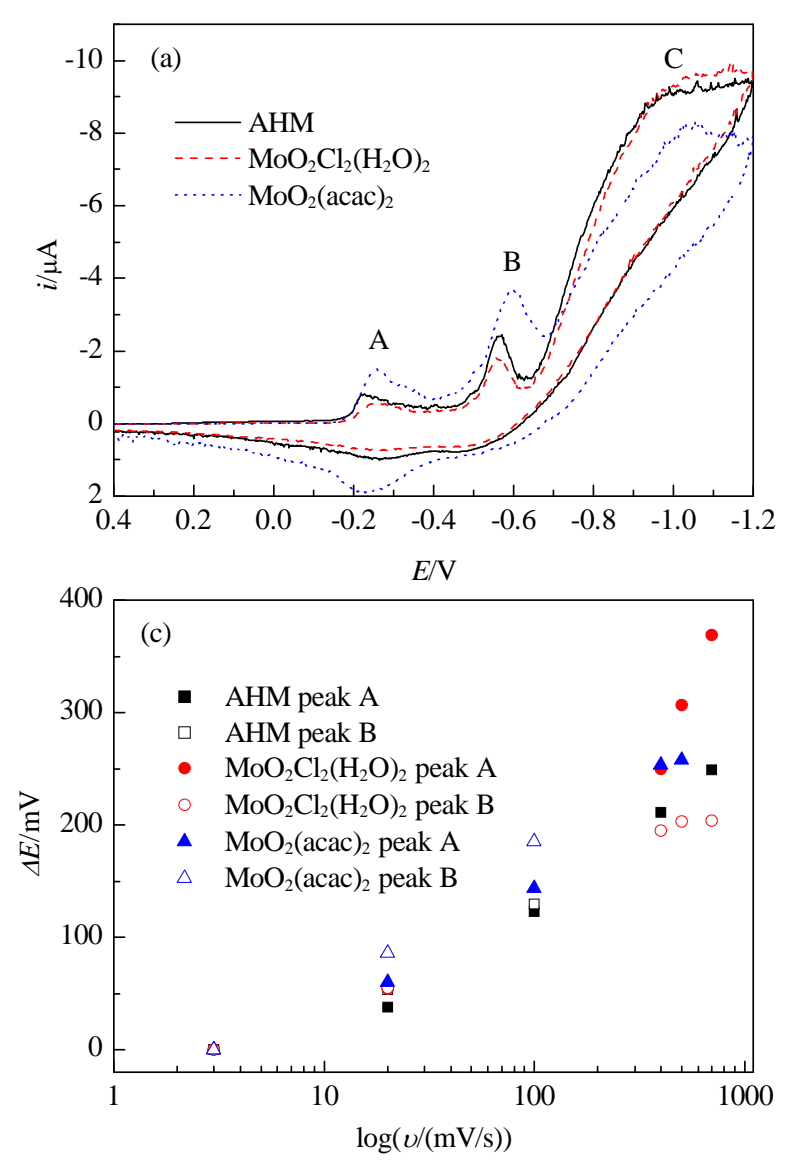

Peaks A and B broaden with increasing scan rate and become less intense (Fig. 7(b)). At high sweep rates, these insertion peaks almost disappear. Electroinsertion into the solid phase is limited by diffusion inside the $\mathrm{MoO}_{3}$ structure, therefore the peaks corresponding to intercalation in more ordered crystalline structure are expected to disappear at low scan rates, whereas the intercalation signals for more open structure disappear at higher scan rates. The rate of the decrease in the intercalation signal intensity with increasing sweep rate was therefore lowest for the sample prepared from the $\mathrm{MoO}_{2} \mathrm{Cl}_{2}\left(\mathrm{H}_{2} \mathrm{O}\right)_{2}$ precursor; the signal for this precursor disappeared at scan rates $>700 \mathrm{mV} / \mathrm{s}$, whereas for the other precursors it disappeared at scan rates of $400-500 \mathrm{mV} / \mathrm{s}$.

Integration of the cathodic and anodic peaks after the first cycle indicates that the insertion process is almost irreversible (Fig. 7(a)). The anodic peak area, assigned to $\mathrm{Na}^{+}$deinsertion, is smaller than the cathodic one by ca. $75 \%-90 \%$, depending on the precursor, indicating that only $10 \%-25 \%$ of the insertion/deinsertion transfers are reversible. For reversible processes, the reduction potential is independent of the sweep rate, therefore the irreversibility is confirmed by the dependence of the reduction potential on the sweep rate (Fig. 7(b) and (c)). The observed irreversibility of intercalation cannot therefore be solely assigned to slow diffusion of $\mathrm{Na}^{+}$into $\mathrm{MoO}_{3}$ structure.
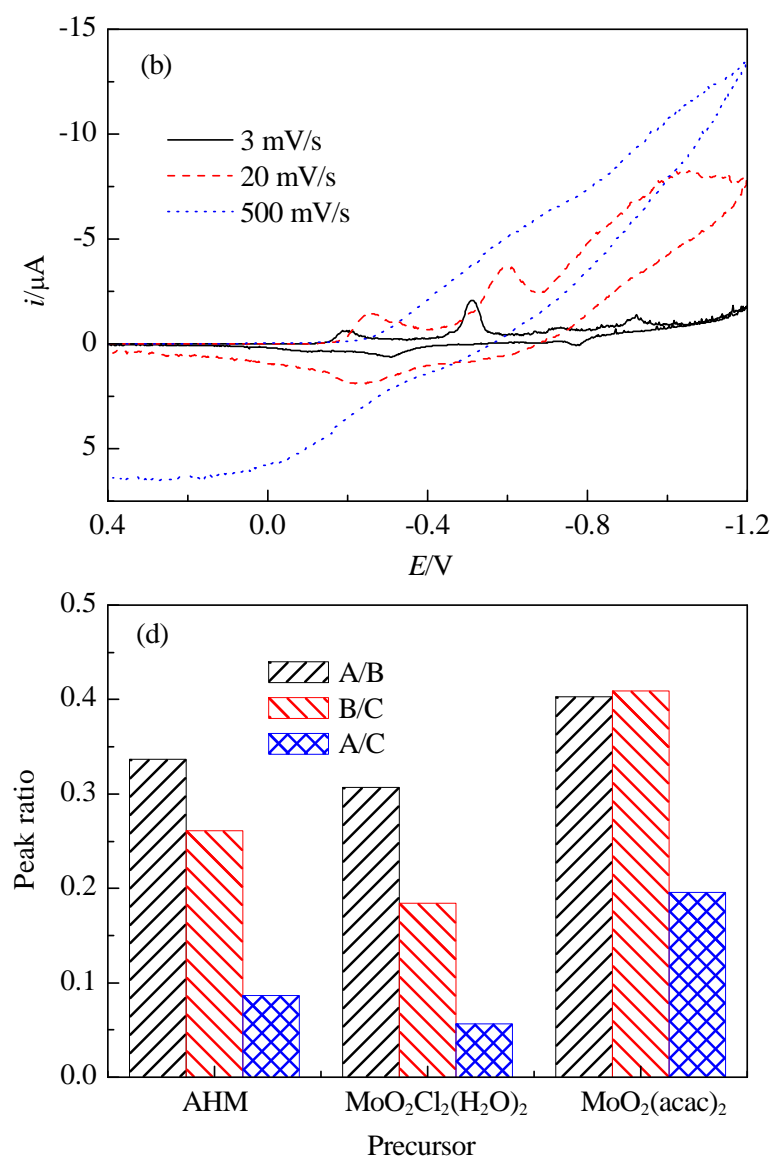

Fig. 7. (a) Cyclic voltammograms of samples prepared from different precursors at a scan rate (v) of $20 \mathrm{mV} / \mathrm{s}$; (b) Cyclic voltammograms of $\mathrm{MoO}_{2}(\mathrm{acac})_{2}$ at various scan rates; (c) Potential shift with increasing scan rate; (d) Ratios of all three peaks. 
The intercalated $\mathrm{Na}^{+}$is trapped in the catalyst structure because of the electrochemically irreversible formation of molybdenum bronzes consisting of molybdenum species with various oxidation states [33]. The irreversible $\mathrm{Na}^{+}$uptake can therefore be correlated with the proportion of molybdenum available in oxidation states other than +6 . This proportion is expected to be highest in the case of the $\mathrm{MoO}_{2} \mathrm{Cl}_{2}\left(\mathrm{H}_{2} \mathrm{O}\right)_{2}$ precursor, because it has the highest dependence of the reduction potential on the sweep rate among the precursors tested (see Fig. 7(c)).

If a second consecutive scan is performed, a significant decrease in the reduction peak height and a slight positive potential shift are observed. The insertion of $\mathrm{Na}^{+}$ions is energetically easier for molybdenum oxide species with some degree of structural disorder, causing decreases in the intensity of the intercalation peaks in consecutive scans [33,34]. A comparison of the ratios of the heights of peaks $\mathrm{A}, \mathrm{B}$, and $\mathrm{C}$ in consecutive scans shows that the $\mathrm{MoO}_{2} \mathrm{Cl}_{2}\left(\mathrm{H}_{2} \mathrm{O}\right)_{2}$ precursor exhibits the most pronounced extinction of the intercalation peaks (Fig. $7(d)$ ), indicating the presence of a more open structure containing more oxygen vacancies. Because of the uncertainty regarding the amount of powder sample on the surface of the electrode, the absolute values of the peak heights cannot be directly compared.

Gradual deactivation was observed for all the catalysts, and the deactivated catalysts were characterized. The UV-Vis spectra of $10 \% \mathrm{MoO}_{3}$ contents indicated the presence of only octahedrally coordinated molybdenum in both the fresh and used catalysts. Transformation of the octahedral coordination to other coordination states (e.g., tetrahedral) can therefore be ruled out as the cause of deactivation. As the reaction temperature was well below the calcination temperature, no significant recrystallization was detected in the XRD patterns of the spent catalysts.

In an attempt to regenerate the spent $\mathrm{MoO}_{2} \mathrm{Cl}_{2}\left(\mathrm{H}_{2} \mathrm{O}\right)_{2}$-based catalyst, after $8 \mathrm{~h}$ of time on stream the temperature was raised to $570{ }^{\circ} \mathrm{C}$ and the reactant stream was switched to air for $3 \mathrm{~h}$. This procedure removed virtually all the carbonaceous deposits, but this did not improve the catalytic activity or selectivity. The voltammetric patterns of the fresh, spent, and regenerated catalysts differed from each other in several ways. Unsurprisingly, the highest redox currents were observed for the spent catalyst (Fig. 8); the carbon deposits, which are electrically conductive and covered the catalyst surfaces, led to an increase in both the cathodic and anodic currents compared with the other two types of sample. For the regenerated catalysts, the currents at the most positive potentials were not higher than those for the fresh catalysts, therefore removal of the carbonaceous deposits during the regeneration step is presumed. However, for the spent, and, most significantly, the regenerated catalysts, clear suppression of peak A occurred at about -0.25 $\mathrm{V}$. The regenerated catalysts showed higher electroactivity at more negative currents. It is well known that it is easier to remove an electron from kinks and steps than from well-developed crystals. For the same electroactive compound, therefore, the more negative the potential of a particular peak in the voltammogram is, the more ordered the structure is.

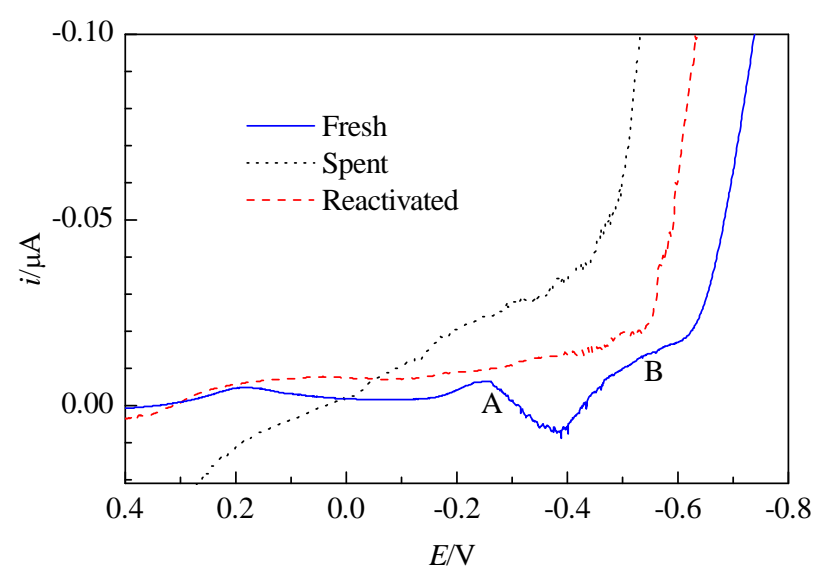

Fig. 8. Voltammograms of fresh, spent, and reactivated catalysts prepared from $\mathrm{MoO}_{2} \mathrm{Cl}_{2}\left(\mathrm{H}_{2} \mathrm{O}\right)_{2}$ precursor at scan rate $v=20 \mathrm{mV} / \mathrm{s}$.

In the case of the $\mathrm{MoO}_{2} \mathrm{Cl}_{2}\left(\mathrm{H}_{2} \mathrm{O}\right)_{2}$ precursor, TEM and XRD show no evidence of crystallization, and the UV-Vis spectra indicate that there is still octahedrally coordinated molybdenum in $\mathrm{MoO}_{3}$; however, voltammetric analysis indicates the loss of kinks and steps in the spent catalyst, which leads to deactivation.

\subsection{Catalytic activity testing}

The use of AHM as a molybdenum source resulted in low epoxidation activity, and PO selectivity not exceeding 10\%; the two main oxidation products were acrolein and $\mathrm{CO}_{2}$. The acroleine: $\mathrm{CO}_{2}$ yield ratio was constant, around 2:1, throughout the experiments (Fig. 9(c)).

Compared with the partly crystalline molybdenum species in the AHM-based catalyst, the mostly crystalline $\mathrm{MoO}_{3}$ in the $\mathrm{MoO}_{2}$ (acac) 2-based catalyst led to a decrease in the selectivity for acrolein formation and an increase in the selectivity for $\mathrm{CO}_{2}$ and allyl alcohol. The propylene conversion remained comparable to that observed in the case of the AHM-based catalyst, with a slight increase in the PO yield (Fig. 9(a)).

The product distribution in propylene oxidation over the $\mathrm{MoO}_{2} \mathrm{Cl}_{2}\left(\mathrm{H}_{2} \mathrm{O}\right)_{2}$-based catalyst, compared with those obtained using the other precursors, was clearly more favorable in terms of epoxidation activity; the PO selectivity increased to $45 \%-60 \%$ at $4 \%-6 \%$ PO yields (Fig. 9(b)). The propylene conversion observed using this molybdenum precursor was practically independent of the molybdenum loading; however, at low molybdenum loadings, the selectivity for PO deteriorated. At molybdenum loadings of $1 \%$ and $2 \%$, the acrolein and acetone yields exceeded that of PO.

In principle, for propylene epoxidation over a bismuth-molybdenum mixed oxide catalyst, three distinct situations are possible: (i) bismuth and molybdenum oxides acting on their own, (ii) bismuth and molybdenum oxides existing as separate phases but interacting electronically, and (iii) bismuth and molybdenum occurring in a single phase. To the best of our knowledge, no significant evidence for case (iii) has been reported for propylene epoxidation.

Silica-supported bismuth oxide, introduced either via im- 

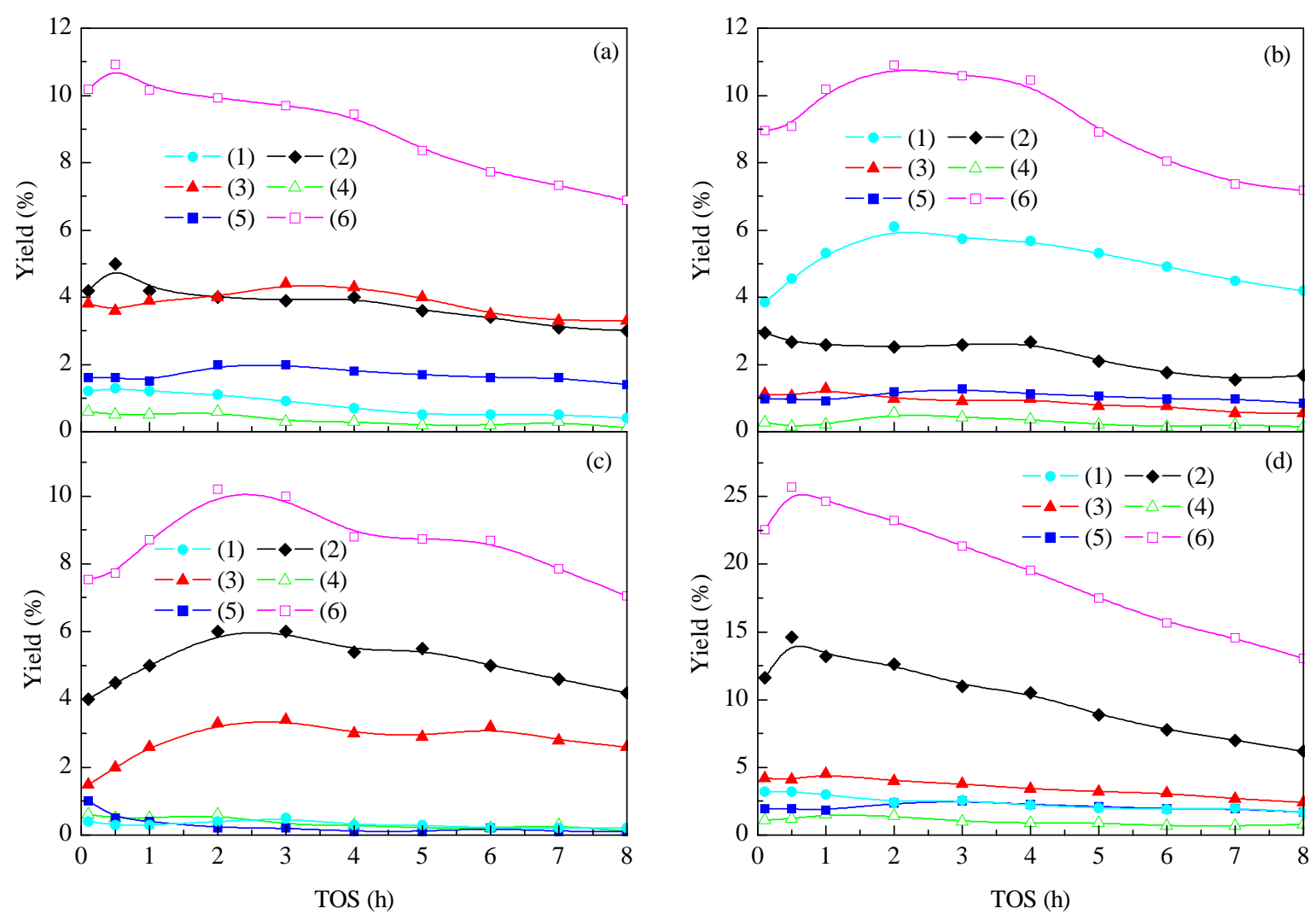

Fig. 9. Catalytic performance of $10 \% \mathrm{MoO}_{x} / \mathrm{SiO}_{2}$ catalysts prepared from different molybdenum precursors. (a) $\mathrm{MoO}_{2}(\mathrm{acac})_{2} ;(\mathrm{b}) \mathrm{MoO}_{2} \mathrm{Cl}_{2}\left(\mathrm{H}_{2} \mathrm{O}\right)_{2} ;(\mathrm{c})$ AHM; (d) PVD-prepared bismuth-molybdenum catalyst. (1) PO; (2) Acrolein; (3) $\mathrm{CO}_{2}$; (4) Acetone; (5) Allyl alcohol; (6) Propylene conversion.

pregnation from bismuth nitrate solution or deposited during a gelation step with TEOS, i.e., with bismuth as the only metallic component, was mostly unselective in propylene epoxidation; the main oxidation product was $\mathrm{CO}_{2}$, with selectivity above $70 \%$. The PO yields achieved over bismuth-containing catalysts were an order of magnitude lower than those observed over molybdenum catalysts prepared from the $\mathrm{MoO}_{2} \mathrm{Cl}_{2}\left(\mathrm{H}_{2} \mathrm{O}\right)_{2}$ precursor.

The propylene conversion increased nearly two-fold for PVD-prepared bismuth-molybdenum catalysts compared with the Aerosil 200-supported ones (Fig. 9(d)). However, the product distribution of the as-prepared catalyst did not indicate significant epoxidation activity. The PO selectivity remained below $15 \%$, and the main oxidation product was acrolein. Similar results were observed when the Aerosil 200-supported molybdenum-based catalysts, described above, were additionally impregnated with bismuth nitrate solution. These results indicate that although bismuth has some epoxidation activity, it is inferior to that of molybdenum. Moreover, the PVD-prepared bismuth-molybdenum catalysts showed enhanced propylene conversion, but this did not lead to an improvement in the epoxidation activity. Although we previously reported the promoting effects of bismuth oxides on the epoxidation reactivity over molybdenum oxides [2], in our experiments the addition of bismuth to the molybdenum catalysts (introduced either by impregnation or by deposition of molybdenum and bismuth oxide nanoparticles close to each other, using PVD) improved only the formation of acrolein.

\section{Conclusions}

In the present study, several types of silica-supported molybdenum oxide catalysts were prepared and tested. The morphology of the deposited molybdenum oxides strongly depended on the preparation method. Different types of molybdenum oxides favored the oxidation of propylene by molecular oxygen either to $\mathrm{PO}$ (i.e., vinylic oxidation) or to acrolein, $\mathrm{CO}_{2}$, and other products by allylic oxidation. The most suitable form, an XRD-amorphous molybdenum oxide, which strongly interacted with the silica support, was prepared from an aqueous molybdenyl chloride precursor by wet impregnation, resulting in PO selectivities up to $61 \%$ at propylene conversions up to $10.8 \%$. At low molybdenum loadings, this precursor resulted in pronounced deposition of tetrahedrally coordinated molybdenum species, whereas at higher molybdenum loadings, the octahedral form prevailed. This phenomenon was not observed for the other precursors studied. Partly or completely crystalline $\alpha-\mathrm{MoO}_{3}$ led to PO selectivities of $15 \%$ or less. The structure of the silica support, which consisted of $\mathrm{SiO}_{2}$ nanoparticles of diameter $12 \mathrm{~nm}$, was significantly altered by the molybdenum precursors, indicating that silica cannot be considered merely as an inert support. The anchoring of molybdenum species in the case of the molybdenyl chloride precursor apparently involves not only its interaction with the functional groups of the 
silica, but also a dissolution-precipitation pathway. The AHM precursor caused collapse of the support, therefore it changed the nanostructure to a macrostructure. The interactions of the $\mathrm{MoO}_{3}$ phase with the support seem to be more important than the $\mathrm{MoO}_{3}$ crystallinity, therefore the presence of an amorphous $\mathrm{MoO}_{3}$ phase does not guarantee better epoxidation reactivity. This amorphous $\mathrm{MoO}_{3}$ phase forms large agglomerates in the case of the AHM precursor, but for the $\mathrm{MoO}_{2} \mathrm{Cl}_{2}\left(\mathrm{H}_{2} \mathrm{O}\right)_{2}$ precursor it is homogeneously distributed on the support surface.

Although air as the sole oxidizing agent, without the presence of a coreductant, does not provide selectivity as high as those of the well-known $\mathrm{H}_{2} / \mathrm{O}_{2}$, TS-1 reaction systems [36,37], an appropriate arrangement of the molybdenum species, with strong interactions with the silica support, significantly increases the epoxidation reactivity.

Bismuth oxide had low epoxidation reactivity as an isolated phase or finely distributed over molybdenum oxide moieties. Its effect on the oxidation of propylene therefore arises either from modification of the geometric structure of the active molybdenum oxide phase or from the formation of bismuth molybdate, which, however, does not lead to propylene epoxidation. The data derived from electrochemical analysis of the supported molybdenum oxides confirmed the presence of weakly ordered molybdenum oxide phases in the catalyst with the highest selectivity in propylene epoxidation. The most active molybdenum oxide phase for epoxidation was XRD amorphous, homogeneously distributed on the support, with the molybdenum atoms octahedrally coordinated, and electroactivity in the potential region about $-0.25 \mathrm{~V}$.

\section{Acknowledgements}

A support by VEGA grant 2/0129/13 is acknowledged by I.V.

\section{References}

[1] Nijhuis T A, Makkee M, Moulijn J A, Weckhuysen B M. Ind Eng Chem Res, 2006, 45: 3447

[2] Pang Y J, Chen X H, Xu C Z, Lei Y J, Wei K M. ChemCatChem, 2014, 6: 876

[3] Kizilkaya A C, Senkan S, Onal I.J Mol Catal A, 2010, 330: 107

[4] Shen K, Liu X H, Lu G Z, Miao Y X, Guo Y L, Wang Y Q, Guo Y. J Mol Catal A, 2013, 373: 78

[5] Monnier J R. Appl Catal A, 2001, 221: 73

[6] Zheng X, Zhang Q, Guo Y L, Zhan W C, Guo Y, Wang Y S, Lu G Z. J Mol Catal A, 2012, 357: 106

[7] Chu H, Yang L J, Zhang Q H, Wang Y. J Catal, 2006, 241: 225

[8] Suo Z H, Jin M S, Lu J Q, Wei Z B, Li C. J Nat Gas Chem, 2008, 17: 184

[9] Wu G Q, Wang Y Q, Wang L N, Feng W P, Shi H N, Lin Y, Zhang T, Jin X, Wang S H, Wu X X, Yao P X. Chem Eng J, 2013, 215-216: 306

[10] Liu T, Hacarlioglu P, Oyama S T, Luo M F, Pan X R, Lu J Q. J Catal, 2009, 267: 202

[11] Murata K, Liu Y Y, Mimura N, Inaba M. Catal Commun, 2003, 4: 385

[12] Hashem A M, Groult H, Mauger A, Zaghib K, Julien C M. J Power

\section{Graphical Abstract}

Chin. J. Catal., 2015, 36: 1900-1909 doi: 10.1016/S1872-2067(15)60961-5

Effects of structures of molybdenum catalysts on selectivity in gas-phase propylene oxidation

Martin Šustek, Blažej Horváth*, Ivo Vávra, Miroslav Gál, Edmund Dobročka, Milan Hronec

Slovak University of Technology, Slovakia;

Institute of Electrical Engineering, Slovak Academy of Sciences, Slovakia;

VŠB - Technical University of Ostrava, Czech Republic
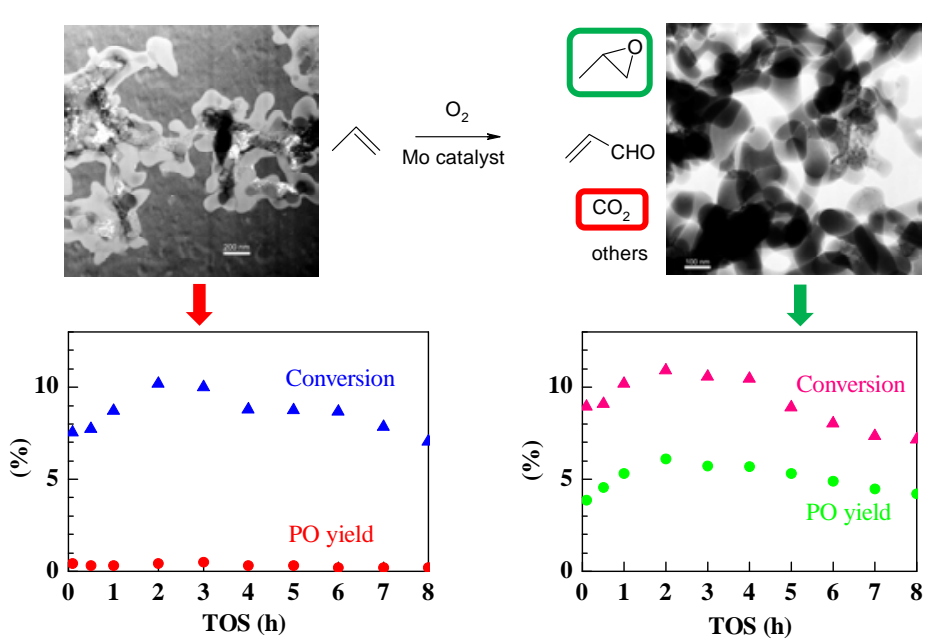

Silica-supported molybdenum-based catalysts were tested for gas-phase epoxidation of propylene. The epoxidation reactivity strongly depended on the nature of the molybdenum precursor. Different molybdenum precursors led to the formation of various distinct nanostructure with different catalytic activity. 
Sources, 2012, 219: 126

[13] Marin Flores O G, Ha S. Appl Catal A, 2009, 352: 124

[14] Horváth B, Hronec M, Vávra I, Šustek M, Križanová Z, Dérer J, Dobročka E. Catal Commun, 2013, 34: 16

[15] Song Z X, Mimura N, Bravo-Suárez J J, Akita T, Tsubota S, Oyama S T. Appl Catal A, 2007, 316: 142

[16] Sian T S, Reddy G B. Sol Energy Mater Sol Cells, 2004, 82: 375

[17] Wang L, Peng B, Peng L N, Guo X F, Xie Z K, Ding W P. Sci Rep, 2013, 3: 2881

[18] Balula S S, Bruno S M, Gomes A C, Valente A A, Pillinger M, Gonçalves I S, MacQuarrie D J, Clark J H. Inorg Chim Acta, 2012, 387: 234

[19] Nguyen H H P, Ohkita H, Mizushima T, Kakuta N. Catal Lett, 2013, 143: 902

[20] Bañares M A. Catal Today, 1999, 51: 319

[21] Rabette P, Olivier D. J Less Common Met, 1974, 36: 299

[22] Klinbumrung A, Thongtem T, Thongtem S. J Nanomater, 2012: 930763

[23] Tokarz-Sobieraj R, Hermann K, Witko M, Blume A, Mestl G, Schlögl R. Surf Sci, 2001, 489: 107

[24] Yuan S P, Wang J G, Li Y W, Peng S Y. Catal Today, 2000, 61: 243

[25] Collart O, Van Der Voort P, Vansant E F, Gustin E, Bouwen A, Schoemaker D, Ramachandra Rao R, Weckhuysen B M,
Schoonheydt R A. Phys Chem Chem Phys, 1999, 1: 4099

[26] Balcar H, Mishra D, Marceau E, Carrier X, Žilková N, Bastl Z. Appl Catal A, 2009, 359: 129

[27] Jeyakumar K, Chand D K. J Chem Sci, 2009, 121: 111

[28] Rempel K U, Williams-Jones A E, Migdisov A A. Geochim Cosmochim Acta, 2008, 72: 3074

[29] Cotton F A, Wilkinson G. Advanced Inorganic Chemistry. 5th ed. New York: John Wiley \& Sons, 1988. 829

[30] Taylor M J, Jirong W, Rickard C E F. Polyhedron, 1993, 12: 1433

[31] Litinskii A O, Narushis Y P, Shatkovskaya D B. J Struct Chem, 1985, 26: 843

[32] Spahr M E, Novak P, Haas O, Nesper R. J Power Sources, 1995, 54: 346

[33] McEvoy T M, Stevenson K J, Hupp J T, Dang X J. Langmuir, 2003, 19: 4316

[34] Dong W, Mansour A N, Dunn B. Solid State Ionics, 2001, 144: 31

[35] Kongmark C, Martis V, Rubbens A, Pirovano C, Löfberg A, Sankar G, Bordes-Richard E, Vannier R N, Van Beek W. Chem Commun, 2009: 4850

[36] Liu Y W, Zhang X M, Suo J S. Chin J Catal (刘义武, 张小明, 索继栓. 催化学报), 2013, 34: 336

[37] Su J, Zhou J C, Liu C Y, Wang X S, Guo H C. Chin J Catal (苏际, 周军 成, 刘春燕, 王祥生, 郭洪臣. 催化学报), 2010, 31: 1195

\title{
钼催化剂结构对其催化气相丙烯环氧化反应选择性的影响
}

\author{
Martin Šustek $^{\text {a }}$, Blažej Horváth ${ }^{\text {a, }}$, Ivo Vávra ${ }^{\text {b,c }}$, Miroslav Gál ${ }^{\text {a }}$, Edmund Dobročka ${ }^{\text {b }}$, Milan Hronec ${ }^{\text {a }}$ \\ 斯洛伐克理工大学化学与食品技术学院, Radlinského 9, 812 37, 布拉迪斯拉发, 斯洛伐克 \\ b 斯洛伐克科学院电气工程研究院, Dúbravská cesta 2, 841 04, 布拉迪斯拉发, 斯洛伐克 \\ ${ }^{c} \mathrm{VŠB}$-俄斯特拉发工业大学纳米技术中心, 17.listopadu 15, 俄斯特拉发, 70800, 捷克共和国
}

\begin{abstract}
摘要: 考察了Mo基催化剂上空气气相氧化丙烯反应. 从无机的和有机金属Mo前驱体出发, 采用浸渍法和物理气相沉积法(PVD) 制备了不同类型的 $\mathrm{SiO}_{2}$ 负载氧化钼和 $\mathrm{Mo}-\mathrm{Bi}$ 复合氧化物催化剂. 透射电镜结果证实, 所制催化剂上环氧化反应活性与其纳米结构 直接有关. 催化剂中出现部分或完全结晶的氧化锄相, 它们与载体 $\mathrm{SiO}_{2}$ 的相互作用较弱, 使得反应生成环氧丙烷的选择性低于 $10 \%$, 而针合在 $\mathrm{SiO}_{2}$ 上的非结晶的八配位 $\mathrm{Mo}$ 物种上的环氧丙烷选择性达 $55 \%$ 以上, 此时丙烯转化率约为 $11 \%$. 不同形貌氧化锄的 电化学表征结果证实了结构缺陷的重要性. 另外, 还讨论了Bi对氧化钿催化环氧化活性的直接促进效应.
\end{abstract}

关键词: 环氧丙烷; 环氧化; 氧化钿; 光学特性; 电化学性质

收稿日期: 2015-06-10. 接受日期: 2015-07-25. 出版日期: 2015-11-20.

*通讯联系人. 电话: +421-2 59325 655; 传真: +421-2 52495 381; 电子信箱: blazej.horvath@stuba.sk

本文的英文电子版由Elsevier出版社在ScienceDirect上出版(http://www.sciencedirect.com/science/journal/18722067). 